
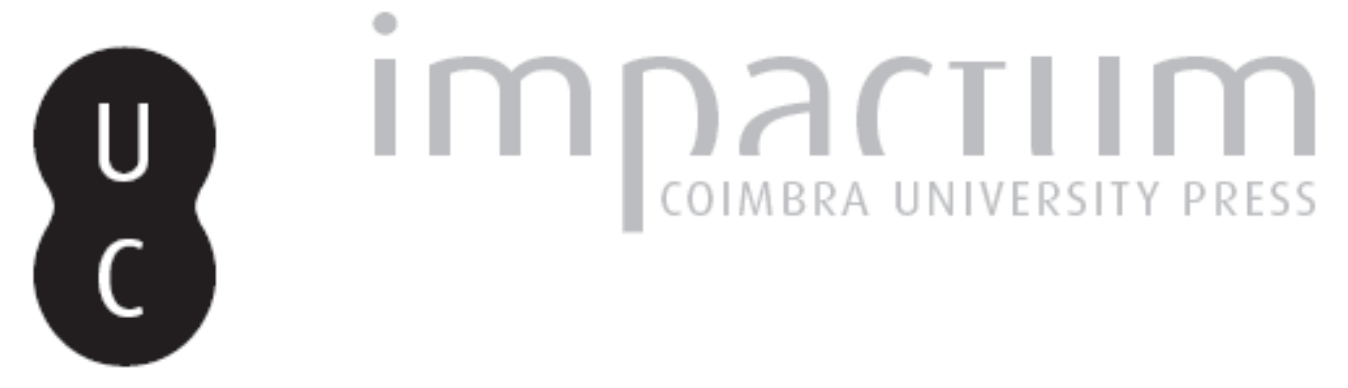

\title{
Changes in stature of Portuguese women born between 1966 and 1982, according to educational level
}

\author{
Autor(es): $\quad$ Conceição, Eunice; Garcia, Susana; Padez, Cristina; Cardoso, Hugo \\ Publicado por: CIAS - Centro de Investigação em Antropologia e Saúde \\ URL \\ persistente: \\ URI:http://hdl.handle.net/10316.2/29595 \\ DOI: \\ DOI:http://dx.doi.org/10.14195/2182-7982_29_6 \\ Accessed : $\quad$ 26-Apr-2023 10:07:21
}

A navegação consulta e descarregamento dos títulos inseridos nas Bibliotecas Digitais UC Digitalis, UC Pombalina e UC Impactum, pressupõem a aceitação plena e sem reservas dos Termos e Condições de Uso destas Bibliotecas Digitais, disponíveis em https://digitalis.uc.pt/pt-pt/termos.

Conforme exposto nos referidos Termos e Condições de Uso, o descarregamento de títulos de acesso restrito requer uma licença válida de autorização devendo o utilizador aceder ao(s) documento(s) a partir de um endereço de IP da instituição detentora da supramencionada licença.

Ao utilizador é apenas permitido o descarregamento para uso pessoal, pelo que o emprego do(s) título(s) descarregado(s) para outro fim, designadamente comercial, carece de autorização do respetivo autor ou editor da obra.

Na medida em que todas as obras da UC Digitalis se encontram protegidas pelo Código do Direito de Autor e Direitos Conexos e demais legislação aplicável, toda a cópia, parcial ou total, deste documento, nos casos em que é legalmente admitida, deverá conter ou fazer-se acompanhar por este aviso.

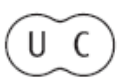




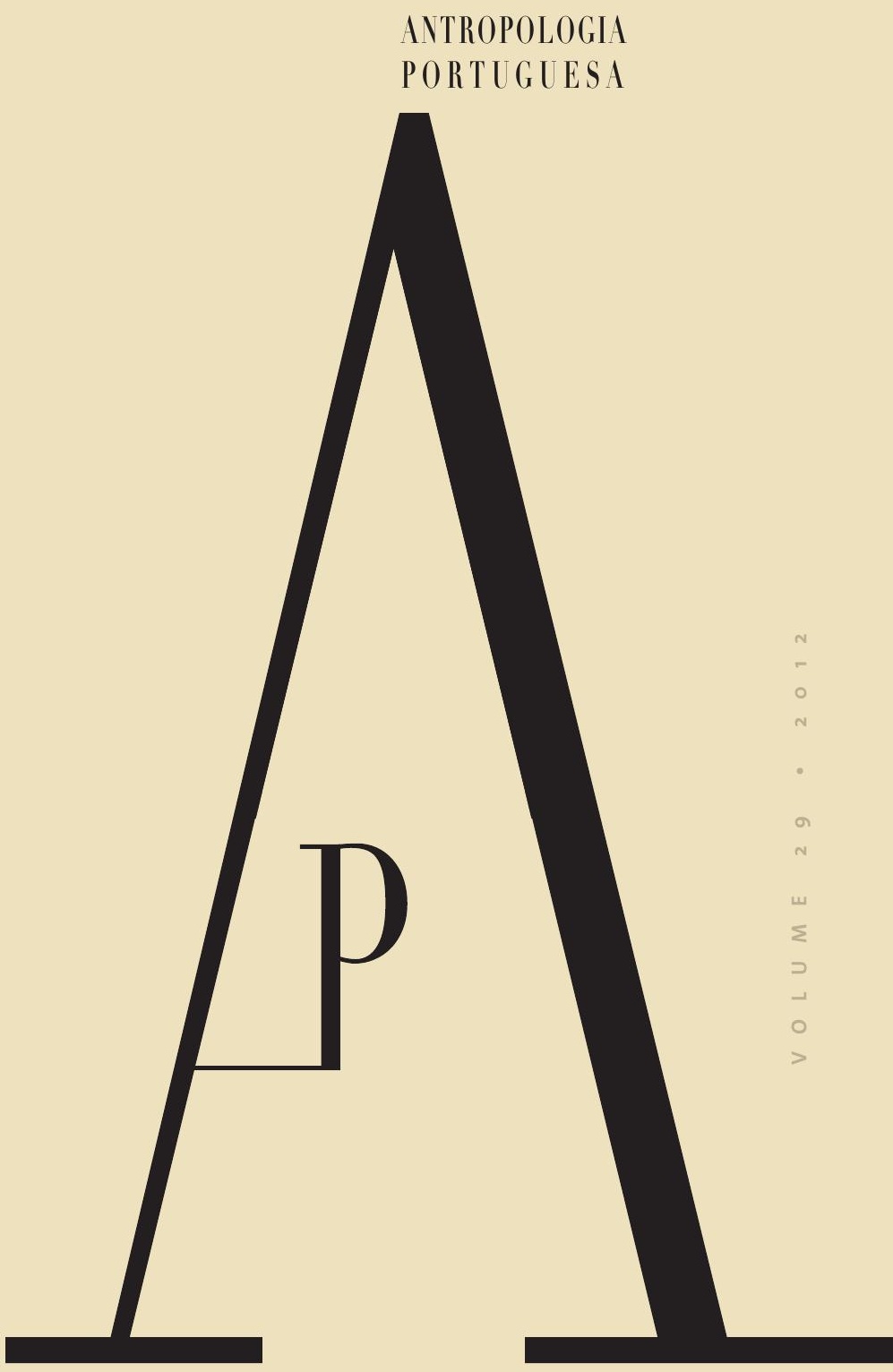

CENTRO DE

INVESTIGAÇ̃̃O

EI ANTROPOLOGIA

E SAÚDE

UNIVERSIDADE

DE COIMBRA 


\section{Changes in stature of Portuguese women born between 1966 and 1982, according to educational level}

\section{Eunice Conceição', Susana Garcia ${ }^{2}$, Cristina Padez ${ }^{3}$, Hugo Cardoso ${ }^{1,4}$}

eunice.conceicao@gmail.com

\begin{abstract}
Studies which document secular change in stature are almost exclusively based on males, while similar data on females is less common. In addition, secular trends in socioeconomic differences of height are seldomly reported. This study aims to document changes in mean stature in a sample of Portuguese women born between 1966 and 1982 ( $n=30,629$ ). For this study self-reported stature data was obtained from a large sample of women who delivered their children at the Dr.
\end{abstract}

Resumo Os estudos publicados sobre a tendência secular da estatura baseiam-se quase exclusivamente em homens, sendo os estudos referentes a mulheres menos comuns. De igual modo, são escassos os estudos que relacionam mudanças seculares na estatura feminina e o nível socioeconómico. O presente estudo pretende documentar a evolução da estatura média de uma amostra de mulheres parturientes nascidas entre 1966 e 1982 ( $n=$ 30 629), assistidas na Maternidade Dr. Alfredo da Costa, em Lisboa, entre 1991 e 2004. Os

\footnotetext{
1 Universidade de Lisboa, Museu Nacional de História Natural e Centro de Biologia Ambiental, Portugal;

${ }^{2}$ School of Social and Political Sciences \& Centre for Public Policies and Public Administration, Technical University of Lisbon, Portugal;

${ }^{3}$ Centro de Investigação em Antropologia e saúde (CIAS), Departamento de Ciências da Vida, Universidade de Coimbra, Portugal

${ }^{4}$ Faculdade de Medicina, Universidade do Porto, Portugal
} 
Alfredo da Costa Maternity Hospital, in Lisbon, between 1991 and 2004. Reported data on educational level was used as a proxy for socioeconomic status to assess changes in female stature in relation to their social class. Results show that female stature in the sample increases during the time period considered (mean stature: $160.8 \mathrm{~cm}$ in 1966 and $161.1 \mathrm{~cm}$ in 1982), but not consistently. In addition, women of higher educational level are systematically taller than their lower educational level counterparts (mean stature difference between highest and lowest educational level groups is 4.2 $\mathrm{cm})$. Compared to males, mean stature increase in females was about 75\% less. Although the time period considered is short, this study documents important socioeconomic differences in female stature and is the first to report stature changes over time in Portuguese women.

Key words Female stature; secular trend; Portugal; socioeconomic factors; $20^{\text {th }}$ century.

\section{Introduction}

Studies on secular trends in stature are almost exclusively based on male data and most are based on military conscript records (van Wieringen, 1986; Komlos, 1987; Padez, 2003). In European countries, the $19^{\text {th }}$ century male height increased rapidly until the early half of the $20^{\text {th }}$ century, slowing down afterwards. dados reportados relativos à estatura e ao nível educacional individual permitiram avaliar a evolução da estatura feminina em relação ao nível socioeconómico. Os resultados mostram que a estatura das mulheres da amostra aumenta durante o período considerado (estatura média 160,8 cm em 1966 e 161,1 em 1982), mas não consistentemente. As mulheres com um nível de escolaridade mais elevado são sistematicamente mais altas em comparação com as mulheres com um nível de escolaridade mais baixo (diferença média de estatura entre o grupo educacional mais alto e o mais baixo é de 4,2 cm). Entre 1966 e 1982, e comparando com a estatura masculina, a estatura feminina aumentou menos 75\%. Apesar do período considerado ser curto, este estudo documenta diferenças socioeconómicas importantes na evolução da estatura feminina e é o primeiro a reportar mudanças na estatura ao longo do tempo em mulheres portuguesas.

Palavras-chave Estatura feminina; tendência secular; Portugal; factores socioeconómicos; séc. XX.

This trend mirrors major improvements in living conditions of the Europeans. In Portugal this positive trend has been documented for the $20^{\text {th }}$ century, with an increase in stature of approximately $0.99 \mathrm{~cm}$ per decade, but accelerated only in the middle to late $20^{\text {th }}$ century (Padez, 2003). Studies reporting changes in female stature are less frequent, since large sources of stature data from females are 
generally unavailable. Several studies on female stature have, nonetheless, been published over the years (Shatrugna and Rao, 1987; Sanna and Danubio, 2009; Wronka and Pawlińska-Chmara, 2007; Komlos, 2010). Some studies found no secular trend (Shatrugna and Rao, 1987) suggesting similar degrees of malnutrition and environmental deprivation between generations, while other studies found a very slow positive trend (Sanna and Danubio, 2009). In general, the secular trend in females is less pronounced when compared with males from the same country and period (Tanner et al., 1982; Kuh et al., 1991).

Social stratification is usually an important determinant of height and health status and income effects are substantial and persistent (Komlos and Kriwy, 2003). In height and growth studies, the socioeconomic status of the individuals is usually estimated from indicators of the socioeconomic environment in which they grow and develop. The most common socioeconomic indicators are the income of the families, place of residence, structure and size of the families, occupation and, the educational level of the parents and physical environment (Entwisle and Astone, 1994; Cardoso, 2005/2006; Wronka and Pawlińska-Chmara, 2007; Schell et al., 2009; de Beer, 2010). Recently, a study by Komlos (2010) reported stature data from the American population, which includes female data with an emphasis on socioeconomic differences. This author analyses a very large sample from the National Health and Nutrition Examination Survey (NHANES) and relates height with socioeconomic variables, namely income and educational level of the individuals. Interestingly, the author describes a height decrease among African American women, resulting on a widening gap in stature between European American and African American females of $1.95 \mathrm{~cm}$. The findings in this study confirm the idea that environmental factors, in this particular case, social inequality, the obesity epidemic and inadequate dietary balance, play a crucial role on stature change. In addition, both men and women of the low-income group were the ones where the height increase was higher, contrasting with the high- and middle-income groups, where height did not change considerably (Komlos, 2010). This is in accordance with other studies which show that secular trend in males tends to be more marked amongst the lower social classes than in the upper ones (Padez, 2003; Komlos and Baur, 2004). In Portugal, Padez (2003) found a difference of almost $4 \mathrm{~cm}$ in height between individuals of high versus low socioeconomic status. Socioeconomic status was based on parental educational level.

Considering the paucity of studies on female secular change and infrequent socioeconomic analysis of height 
trends, our study has three main objectives. Firstly, we wish to document the change in female stature using a sample of Portuguese women born between 1966 and 1982. Secondly, we wish to assess whether the individual's educational level, used as a proxy measure of socioeconomic status, influences changes in stature. Finally, we aim to compare height changes between Portuguese males and females during the same time period. To our knowledge, this is the only Portuguese study reporting changes in female stature based on recent data. For this reason, our study may provide valuable insights into recent changes in the Portuguese female height related to the improvement of the general living and health conditions that occurred in Portugal during the late dictatorship and early democracy years.

\section{Materials and methods}

\section{The sample}

This study analyzed a sample of 30,629 of women who gave birth at the Dr. Alfredo da Costa Maternity Hospital from 1991 to 2004 (Table 1). During this time period, the Maternity collected biographical and medical history data from each of the women which were included in one single database. Stature was among the data collected, which is self-reported by the pregnant woman. The database also includes details of the delivery and of the newborn.

After excluding repeated records and cases not correctly recorded, the baseline sample is composed of 97,388 women born between 1938 and 1991. Since changes in female stature were assessed according to educational level, cases which did not report the women's height and their educational level were excluded. The sample was further selected based on year of birth. In order to compare changes in female stature with previously reported data on Portuguese males born in the same period we only analyzed the sample of women born between 1966 and 1982. For these reasons, the final sample is composed of 30,629 women. The distribution of the sample by year of birth is shown in Table 1. Only women with a minimum of 18 years of age were included in the sample, to insure that growth in height has ceased. The large majority of pregnant women assisted at the Dr. Alfredo da Costa Maternity Hospital lived in the city of Lisbon and its surrounding urban areas, therefore, may be considered representative of the Lisbon urban area. With respect to ethical concerns for the use of this database, all information was made available in an anonymous form. The second source of height data derives from a male sample composed of 19,255 conscripts 


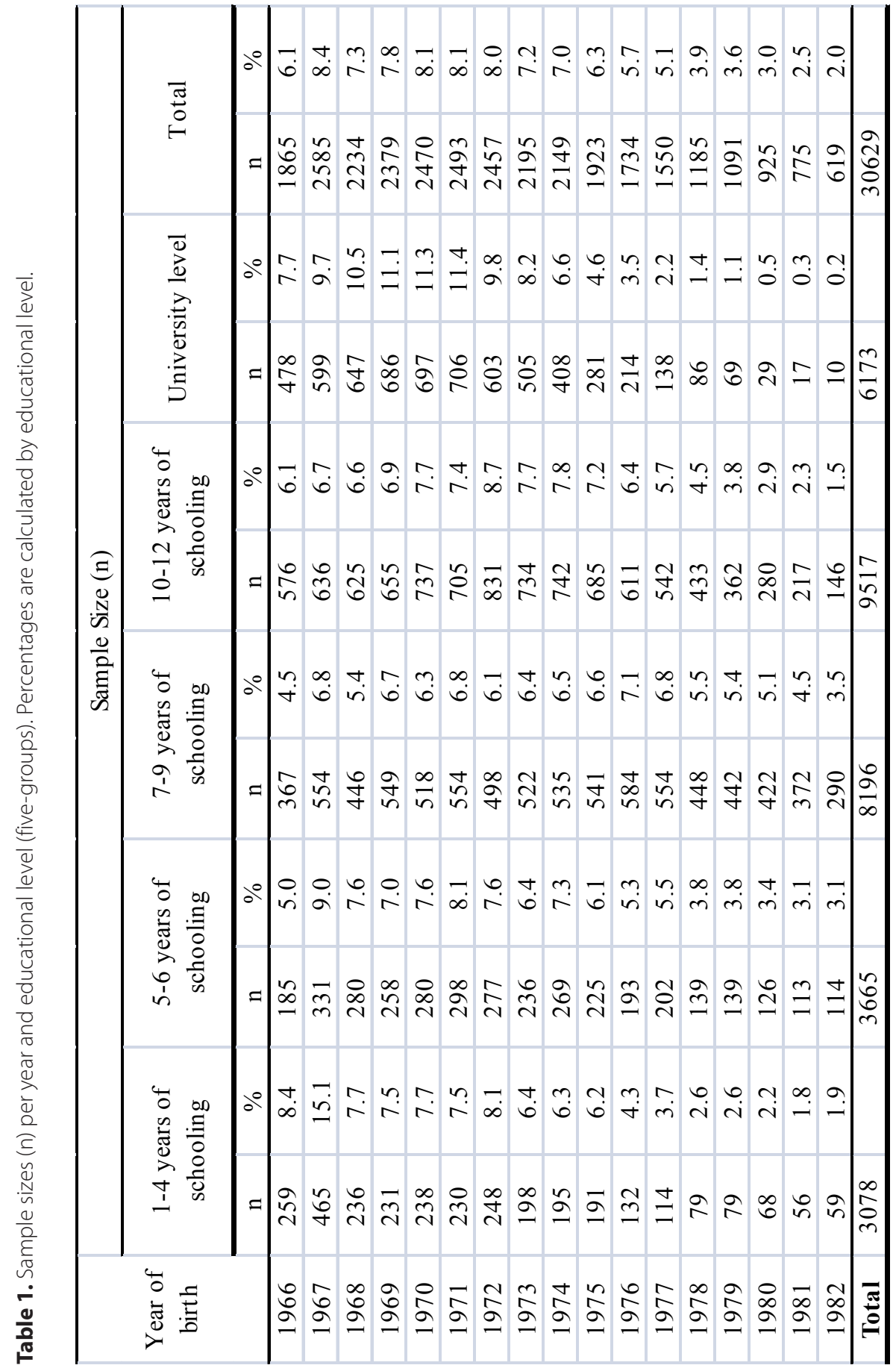


from Lisbon. Military service was compulsory in Portugal up until 2004, and each cohort of males born in a given year was examined by military physicians during the registration visit. Height data were

\section{Socioeconomic status}

Socioeconomic status of the women in the sample was determined from their reported educational level. Women were categorized according to the grades of the Portuguese educational system, which comprises the Ensino Básico ( $\left(1^{\text {st }}\right.$ to $9^{\text {th }}$ grade), Ensino Secundário (10 ${ }^{\text {th }}$ to $12^{\text {th }}$ grade) and Ensino Superior (University). In addition, Ensino Básico is divided into three cycles: Primeiro Ciclo (1 ${ }^{\text {st }}$ to $4^{\text {th }}$ grade), Segundo Ciclo (5 $5^{\text {th }}$ to $6^{\text {th }}$ grade), Terceiro Ciclo ( $7^{\text {th }}$ to $9^{\text {th }}$ grade). Between 1966 and 1986 the compulsory schooling in Portugal was only of 6 years, and in 1986 compulsory schooling was extended to 15 years of age (Ensino Básico). Al- though additional years of schooling lead to an obvious increase in the qualification of the student, it represents a cost for the families. All educational cycles, including the university, are state funded; however, schooling in Portugal is not completely free of charge. Higher levels of education represent considerable financial effort by the families, particularly at the University level.

In the database, educational level was recorded as years of schooling, from 0 to 18 years. The maximum years of schooling recorded (18 years) assumes that the individual completed a University level degree. The possibility of errors when reporting the educational level 'no schooling' should be taken into consideration, since in the database the " 0 " might have been reported either to account women who did not go to school or wrongly reporting women who did not provide information on their educational level. Consequently, all cases reported as " 0 " were excluded from the analysis, including the group of women who, in fact, did not attend school.

Different educational levels as a measure of socioeconomic status may reflect differential exposure of individual health to either positive or negative environments (Komlos, 2010). For this reason, the comparison of women's stature between subgroups that differ in educational level can provide useful information to understand the impact of the environment on growth and development, and, conse- 
quently, final attained height. These comparisons assume that women with more years of schooling originate from higher socioeconomic status families, therefore, had greater access to resources (e.g. like better nutrition, sanitary living conditions or health care) when compared to women with less years of schooling. In Portugal there is a strong connection between parental socioeconomic status and the education level of their children (Instituto Nacional de Estatística, 2010). For illustrative purposes, the sample was divided into the five established educational subgroups, according to the referred Portuguese educational system: (1) Primeiro Ciclo - Ensino Básico (1 ${ }^{\text {st }}$ to $4^{\text {th }}$ grade); (2) Segundo Ciclo - Ensino Básico (5th and $6^{\text {th }}$ grades); (3) Terceiro Ciclo - Ensino Básico ( $7^{\text {th }}$ to $9^{\text {th }}$ grade); (4) Ensino Secundário (10 $0^{\text {th }}$ to $12^{\text {th }}$ grade); (5) Ensino Superior (University level).

In our sample the secondary level is the most represented with $31.1 \%$ of the women having between 10 and 12 years of schooling, followed by women with between 7 and 9 years of schooling (26.8\%) and university level (20.2\%). Twelve per cent of women in our sample had between five and six years of schooling and only $10 \%$ of the women had between one and four years of education. Although in the 1980s near 100\% of the children concluded the Ensino Básico (1 $1^{\text {st }}$ to $4^{\text {th }}$ grade), between 1966 and 2004 the educational level of the Portuguese im- proved considerably. In 1966 only $3.1 \%$ of the Portuguese students were enrolled in the secondary level, but the proportion increased steadily, reaching $12.2 \%$ in 1981 and 40\% in 1991. Presently, more than $60 \%$ of the children with the appropriate age are in fact enrolled in the secondary level and more than half are females (Gabinete de Estatística e Planeamento da Educação, 2009). Consequently, the heterogeneity of the sample reflects these historical trends and the disparities in the ages of the women when they attended the maternity.

\section{Analysis}

Means and standard deviations for female stature were calculated per year and broken down by educational level. Graphs were used to show the relationship between women's height and year of birth by educational level. Differences in mean stature between education groups were compared using an ANCOVA, with year of birth as the covariate. In addition, mean differences of height between the different educational levels during the period from 1966 to 1982 were calculated. Finally, mean increase in female stature during the considered time period was calculated and compared to that of male stature. All statistical tests were carried out using SPSS 
(SPSS Inc., 2008) and with significance level of 0.05 .

\section{Results}

Results show that female stature tends to increase between 1966 and 1982 and those women of higher educational level are systematically taller than those of lower educational level (Table 2). Figure 1 illustrates the changes in mean stature in the women who attended school, according to five groups of educational level. Women with no schooling were excluded because they could not be effectively included (see above). A clear difference in height between women of different educational levels can be observed. Women of lower educational levels are consistently shorter than women of higher educational levels and mean height calculated per year of birth of women with lower education level never surpasses mean height of women of higher educational level. The mean dif- ference between these two groups is 4.2 $\mathrm{cm}$. However, mean heights overlap in groups with 1 to 4 years of schooling and with 5 to 6 years of schooling (for the years 1966, 1970 and 1978), as well as in groups with 10 to 12 years of schooling and University studies (year 1979). The ANCOVA results showed that there is a significant effect of educational level on stature, even after controlling for year of birth ( $F=83.86$, $p<0.01)$.

Data in Figure 1 shows that female stature increased during the time period considered, although not consistently, regardless of the educational level of the women in the sample. However, a decrease in mean height in women born in 1979 in every educational group can be visually detected, except in women with 10-12 years of schooling. After this year the mean stature seems to recover, only to decrease again until 1982, although reported mean height in 1982 is still superior to the mean height reported in 1966, with the exception of the 1-4 years of schooling group.

Table 2. Mean female height ( $\mathrm{cm}$ ) according to educational groups.

\begin{tabular}{lccc}
\hline Educational Groups & Mean Height $(\mathrm{cm})$ & $\mathrm{sd}$ & $\mathrm{N}(\%)$ \\
\hline 1 - 4 years of schooling & 158.6 & 6.55 & $3078(10.0 \%)$ \\
5 - 6 years of schooling & 159.7 & 6.38 & $3665(11.9 \%)$ \\
7 - 9 years of schooling & 161.0 & 6.44 & $8196(26.8 \%)$ \\
10 - 12 years of schooling & 162.2 & 6.41 & $9517(31.1 \%)$ \\
University & 162.8 & 6.08 & $6173(20.2 \%)$ \\
\hline TOTAL & 160.9 & 6.42 & $30629(100 \%)$ \\
\hline
\end{tabular}




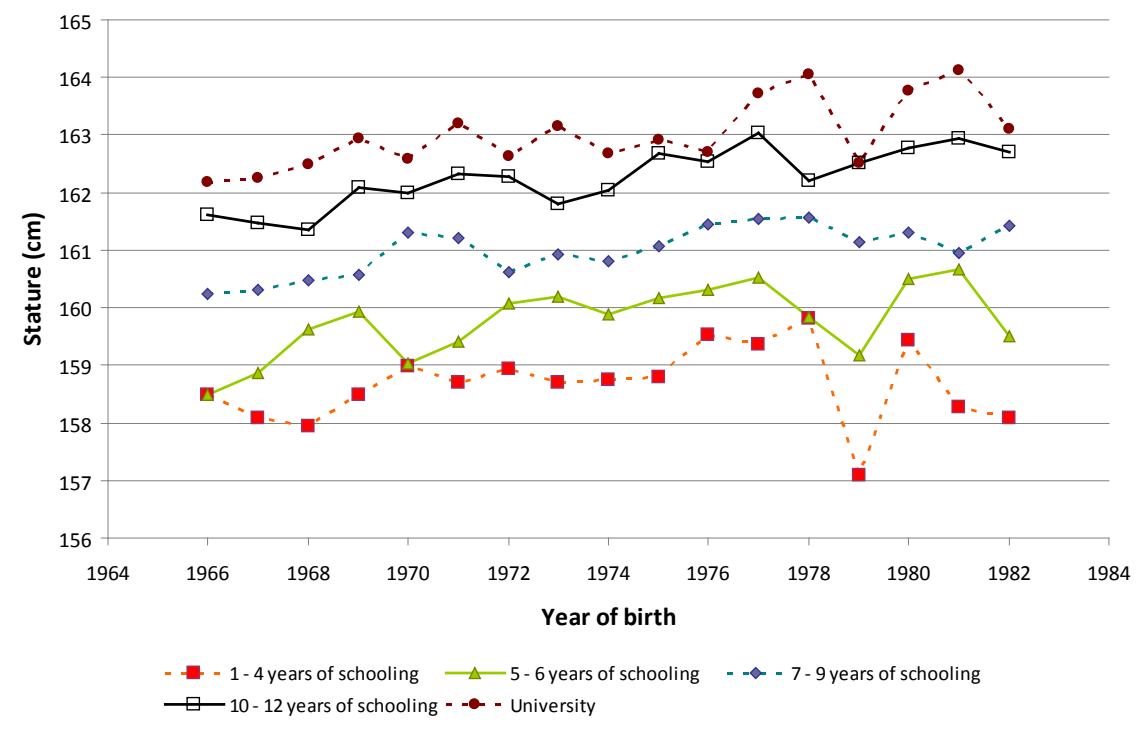

Figure 1. Changes in stature of Portuguese women born between 1966 and 1982, according to educational level (5-group categorization).

Mean differences in height between consecutive educational level groups are $1.11 \mathrm{~cm}, 1.28 \mathrm{~cm}, 1.17 \mathrm{~cm}$ and 0.58 $\mathrm{cm}$, from lowest to highest education. Women with 1 to 4 years of schooling increased in stature until 1978, decreased in 1979, and in 1982 were slightly shorter than they were in the beginning of the period under analysis, showing a mean decrease of $0.41 \mathrm{~cm}(p=0.6495)$. On average, women with 5 to 6 years of schooling increased $1.02 \mathrm{~cm}(p=0.1682)$, whereas women with 7 to 9 years of schooling increased $1.17 \mathrm{~cm}$ ( $p=0.0203)$, women with
10 to 12 years of schooling increased 1.07 $\mathrm{cm}(\mathrm{p}=0.0566)$, and women with over 12 years of schooling increased 0.92 $(p=0.6448)$.

When changes in female stature are compared to that of males born in the same time period (Table 3), men and women born in 1982 are, on average, taller than men and women born in 1966. Mean increase in height among women born in 1966 and 1982 (0.32 cm) was approximately $25 \%$ of the increase in male stature $(1.21 \mathrm{~cm})$ for the same period of time. 
Table 3. Mean heights for Portuguese males and females born in 1966 and 1982.

\begin{tabular}{|c|c|c|c|c|c|}
\hline & \multicolumn{2}{|c|}{ Born in 1966} & \multicolumn{2}{|c|}{ Born in 1982} & \multirow{2}{*}{$\begin{array}{c}\text { Mean difference } \\
\text { between } \\
1966 \text { and } 1982(\mathrm{~cm})\end{array}$} \\
\hline & $\mathrm{N}$ & $\begin{array}{l}\text { Mean height } \\
\pm \mathrm{SD}(\mathrm{cm})\end{array}$ & $\mathrm{N}$ & $\begin{array}{c}\text { Mean height } \\
\pm \mathrm{SD}(\mathrm{cm})\end{array}$ & \\
\hline Female & 1865 & $160.75 \pm 6.28$ & 619 & $161.07 \pm 6.68$ & 0.32 \\
\hline Male & 12,860 & $171.58 \pm 6.52$ & 6395 & $172.79 \pm 6.47$ & 1.21 \\
\hline
\end{tabular}

\section{Discussion}

The overall trend documented in our study is similar to the trend in height of men from Lisbon, born around the same period (Padez, 2003). The positive findings on stature's evolution reflect the improvement in health and general living conditions of the Portuguese. During these decades living standards improve greatly. The creation of a strong welfare state, with the birth of the National Health Care System and of the Social Security System expanded virtually to all population, even to the most needed (Mozzicafreddo, 1992). The Portuguese economy expanded in these decades, but income inequality persisted and, presently, it is still high when compared with other countries of the European Union (Instituto Nacional de Estatística, 2010). However, the time period measured is considerably short and a more consistent increase in stature cannot be assumed.
Comparing groups of women with different educational levels still reveals strong disparities in the Portuguese population. Women of higher educational level are consistently taller than those with a lower educational level. This difference is strikingly visible when comparing women with nine or less years of schooling, which became the Portuguese compulsory schooling level after 1986, with women who attended school for more than nine years (Ensino Secundário - $10^{\text {th }}$ to $12^{\text {th }}$ grade- and Ensino Superior - University). These findings are similar with those of a recent study on the American population, which estimates SES by income, controlling not only the ratio between the income and the size of the household, but also for the educational level of individuals (Komlos, 2010). As in our case, results found by Komlos (2010) and by Fredriks et al. (2000) show that higher educated levels are associated with higher stature in women. Greatest socioeconomic differences in 
stature found in the present study (4.2 $\mathrm{cm})$ are similar to that found in Portuguese males, but over a longer period of time (Padez, 2003).

Two potential sources of bias can be detected in our sample. The first is that stature was self-reported by the women during admission in the maternity hospital, and the second is that women with no schooling were excluded from the final sample. The effects of self-reported stature are probably very small because this is a consistent directional bias, which does not affect the actual variations in height between women over the years, and self-reported information on stature has been considered very reliable (Nakamura et al., 1999; Gozzi et al., 2010). For a similar reason, excluding women with no schooling is unlikely to change variations in stature between groups and years, because they were systematically eliminated. However, this made impossible to assess changes in height at the lowest educational/socioeconomic level.

If one compares the results found in the present study with findings from the only other study of a Mediterranean population (Sanna and Danubio, 2009), Portuguese women in our sample are, on average, taller (mean height $161.2 \mathrm{~cm}$ ) than Italian women from Sardinia (159.1 $\mathrm{cm})$, but are shorter when compared to women from Latium $(162.4 \mathrm{~cm}$ - the Italian region including Rome) (Sanna and Danubio, 2009). Mean increase in height of Portuguese women born between 1966 and 1982 is considerably less than the increase in height of women from both Italian samples born in the same period. Sanna and Danubio (2009) argue that the differences between women from Latium and women from Sardinia are due to the slowing or stabilization of the secular trend in women from Latium, whereas a continuing secular trend is observed for the Sardinian women. The results are difficult to compare because the Italian samples are small (579 and 179) and SES was assessed based on the occupation of the father. Besides, the sample from Latium is composed only of women from middle/upper classes.

Height is a marker of the biological well-being and general health, at the individual and population level, which is mediated by environmental conditions and family lifestyle choices (Komlos, 2010). Studies in other European populations suggest that the secular trend is more marked amongst the lower social classes than in the upper ones, at least in males (Laska-Mierzejewska et al., 1982; Chinn et al., 1989; Padez, 2003; Komlos and Baur, 2004). However, frequently the reverse occurs, where the early impact of improvements in living conditions affect the upper classes first, namely when analysing mortality rates (Marmot et al., 1987; Haines, 1995; Cambois et al., 2001). Victora et al. (2000), for example, have shown that improvements in living and health 
conditions will tend to increase inequity, since the first to benefit are those who are already better off. In a series of papers, Komlos (1987, 1990, 1994, 2008) using diverse samples from $18^{\text {th }}$ and $19^{\text {th }}$ century Europe and the US, shows that marked improvements in the standard of living are not generally translated into an immediate height increase. Indeed, in the early stages of economic development the upper classes will benefit first, and income discrepancies between classes may increase. As social groups diverge, so do their heights. Our data suggest such a tendency if we consider the two extreme educational groups. The most educated women increased in mean height, whereas stature of the least educated fluctuated over time, but at the end of the period under analysis did show a slight decrease. Even if the educational group with a higher difference in height between 1966 and 1982 was a relatively non-educated group (7 to 9 years of schooling), it cannot be concluded that the lower social classes increased more in height. The women belonging to the less educated groups (1 to 4 and 5 to 6 years of schooling) were on average shorter during all the period than the ones belonging to the more educated groups (> 9 years of schooling). Additionally, the first two groups together only increased $0.61 \mathrm{~cm}$ in height compared to an increase of $1.99 \mathrm{~cm}$ in the two most educated groups. Nonetheless, the results do not show a clear tendency for the higher
SES groups to benefit more with better living conditions compared to their lower SES counterparts, because all of the educational groups, except the least educated, seem better off at the 80 's than they were at the end of the 60 's and the height gains, if analysed group by group, were similar. The least educated group, apparently, did not benefit from the improved living standards. A possible reason could be that women born in the 80's who only completed 4 years of schooling belonged to a more homogenous group in terms of low socioeconomic situation than those born in the 60's.

Portuguese males born between 1966 and 1982 showed an almost 4-fold increase in stature compared to the increase in female stature in the same time period. Other studies report a less pronounced secular trend for females (Kuh et al., 1991; Tanner et al., 1982). This difference may be related to historical and cultural factors that explain preferential treatment of parents towards boys, who tend to benefit from the better life opportunities they provide. Although cultural behaviours are now considerably less detrimental to females, in recent history boys tended to have access to more and better resources, like better nutrition and health care, than their female counterparts. In addition, historically, girls have been exposed to a greater risk for neglect and higher workloads (Cardoso, 2005/2006), and are also more exposed to infections since girls most often 
looked after the sick (de Beer, 2010). The sex difference may be related to biological factors. Males are more ecosensitive, as they respond faster to environment modifications of improvement or deterioration (Varela-Silva and Bogin, 2003). However, other authors found no evidence that males are more sensitive to environmental changes than females (Gustafsson et al., 2007). Regardless of cultural and biological factors which may explain sex differences in secular trends of height, living standards in Portugal improved from 1960 to 1980, but did not reach all social classes equally and gross inequalities persisted (Cardoso and Caninas, 2010). Some studies indicate that the gap between the standard of living of the privileged classes and that of the middle and lower classes even widened (Estanque, 2006).

\section{Conclusion}

This study attempts to fill a gap in the literature about secular changes in female stature. Although the period of time considered is short, our findings are important since, to the best of our knowledge, this is the only study reporting changes in Portuguese female stature using recent data. The socioeconomic changes that took place in Portugal in the last three decades are reflected in the increase of mean adult height of men. Our study shows that the increase in the mean height of women is less pronounced, but the trend is, in general, positive. All educational groups increase in height between 1966 and 1982, except for the least educated group (1 to 4 years of schooling) which apparently did not benefit from the improvement of the living conditions. The cause for the sex difference deserves further investigation, but evidence points to important historical and cultural factors which could have been favourable to men. This study has implications for the understanding of future height change in Portugal. Taking into consideration that secular changes in stature are not necessarily positive, but may be negative, depending on the social and economic conditions of a given society, the present time of incertitude, together with the income and social inequality already documented to the period between 1960 and 1982, is likely to result in unexpected consequences for the secular trend in height of the Portuguese.

\section{Acknowledgments}

We would like to thank the Dr. Alfredo da Costa Maternity Hospital and the Portuguese Army Command (Estado Maior do Exército) for their kindness in providing all the raw data. Acknowledgements are due to the two anonymous referees for their insightful comments and corrections. 


\section{Bibliographic references}

Cambois, E.; Robine, J.-M.; Hayward, M. D. 2001. Social inequalities in disability-free life expectancy in the French male population 1980-1991. Demography, 38(4): 513-524.

Cardoso, H. F. V. 2005/2006. A quantificação do estatuto socioeconómico em populações contemporâneas e históricas: dificuldades, algumas orientações e importância na investigação orientada para a saúde. Antropologia Portuguesa, 22/23: 247-272.

Cardoso, H. F. V.; Caninas, M. 2010. Secular trends in social class differences of height, weight and BMI of boys from two schools in Lisbon, Portugal (19102000). Economics and Human Biology, 8(1): 111-120.

Chinn, S.; Rona, R. J.; Price, C. E. 1989. The secular trend in height of primary school children in England and Scotland 1972-79 and 1979-86. Annals of Human Biology, 16(5): 387-395.

de Beer, H. 2010. Physical stature and biological living standards of girls and young women in the Netherlands, born between 1815 and 1865. The History of the Family, 15(1): 60-75.

Entwisle, D. R.; Astone, N. M. 1994. Some practical guidelines for measuring youth's race/ethnicity and socioeconomic status. Child Development, 65(6): 1521-1540.

Estanque, E. 2006. A questão social e a democracia no início do século XXI - participação cívica, desigualdades sociais e sindicalismo. Revista Finisterra, 55-56-57: 77-99.
Fredriks, A. M.; van Buuren, S.; Burgmeijer, R. J.; Meulmeester, J. F.; Beuker, R. J.; Brugman, E.; Roede, M. J.; Verloove-vanhorick, S. P.; Wit, J. M. 2000. Continuing positive secular growth change in the Netherlands 1955-1997. Pediatric Research, 47(3): 316-323.

Gabinete de Estatística e Planeamento da Educação. 2009. 50 anos de estatísticas da educação. Lisboa, Instituto Nacional de Estatística.

Gozzi, T.; Flück, C.; L' Allemand, D.; Dattani, M. T.; Hindmarsh, P. C.; Mullis, P. E. 2010. Do centimetres matter? Self-reported versus estimated height measurements in parents. Acta Paediatrica, 99(4): 569-574.

Gustafsson, A.; Werdelin, L.; Tullberg, B. S.; Lindenfors, P. 2007. Stature and sexual stature dimorphism in Sweden, from the 10th to the end of the 20th century. American Journal of Human Biology, 19(6): 861-870.

Haines, M. R. 1995. Socio-economic differentials in infant and child mortality during mortality decline: England and Wales 18901911. Population Studies, 49(2): 297-315.

Instituto Nacional de Estatística. 2010. Sobre a pobreza, as desigualdades e a privação material em Portugal. Lisboa, INE.

Komlos, J. 1987. The height and weight of West Point cadets: dietary change in antebellum America. The Journal of Economic History, 47(4): 897-927.

Komlos, J. 1990. Height and social status in eighteenth-century Germany. Journal of Interdisciplinary History, 20(4): 607621. 
Komlos, J. 1994. The nutritional status of French students. Journal of Interdisciplinary History, 24(3): 493-508.

Komlos, J. 2008. On English pygmies and giants: the physical stature of English youth in the late $18^{\text {th }}$ and early $19^{\text {th }}$ centuries. In: Field, A. J.; Clark, G.; Sundstrom, W. A. (ed.). Research in Economic History. Vol. 25. Amsterdam, Elsevier: 149-168.

Komlos, J. 2010. The recent decline in the height of African-American women. Economics and Human Biology, 8(1): 58-66.

Komlos, J.; Kriwy, P. 2003. The biological standard of living in the two Germanies. German Economic Review, 4(4): 459-473.

Komlos, J.; Baur, M. 2004. From the tallest to (one of) the fattest: the enigmatic fate of the size of the American population in the twentieth century. Economics and Human Biology, 2(1): 57-74.

Kuh, D. L.; Power, C.; Rodgers, B. 1991. Secular trends in social class and sex differences in adult height. International Journal of Epidemiology, 20(4): 1001-1009.

Laska-Mierzejewska, T.; Milicer, H.; Piechaczek, H. 1982, Age at menarche and its secular trend in urban and rural girls in Poland. Annals of Human Biology, 9(3): 227-233.

Marmot, M. G.; Kogevinas, M.; Elston, M. A. 1987. Social/economic status and disease. Annual Review of Public Health, 8: 111-135.

Mozzicafreddo, J. 1992. O estado-providência em Portugal: estratégias contraditórias.
Sociologia - Problemas e Práticas, 12: 57-88.

Nakamura, K.; Hoshino, Y.; Kodama, K.; Yamamoto, M. 1999. Reliability of self-reported body height and weight of adult Japanese women. Journal of Biosocial Science, 31(4): 555-558.

Padez, C. 2003. Secular trend in stature in the Portuguese population (1904-2000). Annals of Human Biology, 30(3): 262278.

Sanna, E.; Danubio, M. E. 2009. Are changes in body dimensions of adult females from Italy (Sardinia and Latium) related to secular trend? Journal of Comparative Human Biology, 60(5): 451-460.

Schell, L. M.; Gallo, M. V.; Ravenscroft, J. 2009. Environmental influences on human growth and development: historical review and case study of contemporary influences. Annals of Human Biology, 36(5): 459-477.

Shatrugna, V.; Rao, K. V. 1987. Secular trends in the heights of women from the urban poor community of Hyderabad. Annals of Human Biology, 14(4): 375-377.

SPSS Inc. 2008. SPSS Version 17.0 for Windows User's Guide. Chicago, SPSS Inc.

Tanner, J. M.; Hayashi, T.; Preece, M. A.; Cameron, N. 1982. Increase in length of leg relative to trunk in Japanese children and adults from 1957 to 1977: comparison with British and with Japanese Americans. Annals of Human Biology, 9(5): 411-423.

van Wieringen, J. C. 1986. Secular growth changes. In: Falkner, F.; Tanner, J. M. 
(eds.). Human growth: a comprehensive treatise. Vol. 3. New York, Plenum Press: 307-331.

Varela-Silva, M. I.; Bogin, B. 2003. Growth as a measure of socioeconomic inequalities and poor living conditions among Portuguese, Cape Verdean-Portuguese, and Cape Verdean children, between 1993 and 2001. In: Proceedings of the $1^{\text {st }}$ Lusophone Africa Conference: Intersections between the Social Sciences [Online]. Ithaca, Cornell University: 1-17. [Acedido em 9 de Agosto de 2004]. Disponível em: www.kyle.aem.cornell. edu/ lusopaps/Varela-Silva_\&_Bogin. pdf.

Victora, C. G.; Vaughan, J. P.; Barros, F. C.; Silva, A. C.; Tomasi, E. 2000. Explaining trends in inequalities: evidence from Brazilian child health studies. The Lancet, 356(9235): 1093-1098.

Wronka, I.; Pawlińska-Chmara, R. 2007. Childcare, height and BMI among female Polish university students, 2005. Economics and Human Biology, 5(3): 435-442. 